\title{
NOTE
}

\section{Occurrence of migrating silver eels Anguilla japonica in the East China Sea}

\author{
Seiji Sasai*, Jun Aoyama, Shun Watanabe, Toyoji Kaneko, Michael J. Miller, Katsumi Tsukamoto
}

Ocean Research Institute, The University of Tokyo, 1-15-1 Minamidai, Nakano, Tokyo 164-8639, Japan

\begin{abstract}
The seasonal occurrence of 72 silver phase Japanese eels Anguilla japonica collected in the East China Sea is described and their morphological features analyzed. These silver eels were captured with dip nets under lights around fishing boats at night near islands in the northeast region of the East China Sea over 7 yr. The eels had the typical morphological characteristics of silver eels, such as a black metallic body color and enlarged eyes. All females had started ovarian maturation with gonad somatic indices of 1.3 to 3.5. No eels smaller than $400 \mathrm{~mm}$ or yellow phase eels were collected or observed. Considering the limited seasonal occurrence of these eels, and that their morphological features were characteristic of silver phase migrating eels, these eels appeared to be passing through sampling areas on their spawning migration to the region just west of the Mariana Islands in the Philippine Sea.
\end{abstract}

KEY WORDS: Anguilla japonica · Silver eels · Spawning migration $\cdot$ East China Sea

Resale or republication not permitted without written consent of the publisher

In recent years, there have been numerous studies on the early life history of Japanese eel Anguilla japonica that have provided valuable information on the leptocephalus and glass eel stages (Tsukamoto 1990, 1992, Tzeng 1990, Arai et al. 1997, Kawakami et al. 1999). In contrast, knowledge about the adults of this species during their spawning migration in the ocean is limited, because migrating silver eels are rarely collected once they leave estuarine and coastal areas. Although the distribution of small leptocephali has indicated that the spawning area of this species is in the North Equatorial Current west of the Mariana Islands (Tsukamoto 1992), direct evidence, such as collection of fertilized eggs or observations of spawning adults, has not yet been obtained.

\footnotetext{
*E-mail: sasai@ori.u-tokyo.ac.jp
}

Due to the difficulty in collecting migrating eels over deep water, information on the spawning migration of adult of anguillid eels in the ocean is scarce. However, Bast \& Klinkhardt (1988) reported on a specimen of European eel Anguilla anguilla that was collected east of the Azores Islands, and discussed a few other specimens, including 2 eels from near the Faroe Islands (Reinsch 1968, Ernst 1975). In the case of the American eel A. rostrata only 16 silver eels have ever been reported in coastal areas (Wenner 1973, Tesch 1977). Similarly, there are only a few reports on the occurrence of silver eels of $A$. japonica in continental shelf waters (Matsui 1957, Honma 1966, Tabeta 1980, Ogata et al. 1991, Mochioka pers. comm.). Most of these were reports of silver eels caught in the East China Sea, which is a large area of continental shelf that is surrounded by Taiwan, China, Korea, and the southern Islands of Japan. The 28 silver eels reported to have been caught in this area during the past $50 \mathrm{yr}$ were bycatch of trawls or were dip netted during the mackerel fishery (Matsui 1957). However, few eels have been captured after the decline of the mackerel fishery, and previous reports only contained limited information. Recently, we discovered 2 locations in the northeast region of the East China Sea, just west of southern Japan, where silver eels were consistently observed every year during late fall and winter and obtained samples of these eels over a 7 yr period.

The objectives of this study were to determine the seasonal occurrence of the silver eels collected in this region and to describe their morphological features that were indicative of reproductive maturation. We also summarize historical reports on the occurrence of silver eels in the East China Sea and discuss the significance of these catches of silver eels during the early stages of their spawning migration in relation to recent studies on the otolith microchemistry of these marinecaught silver eels. 


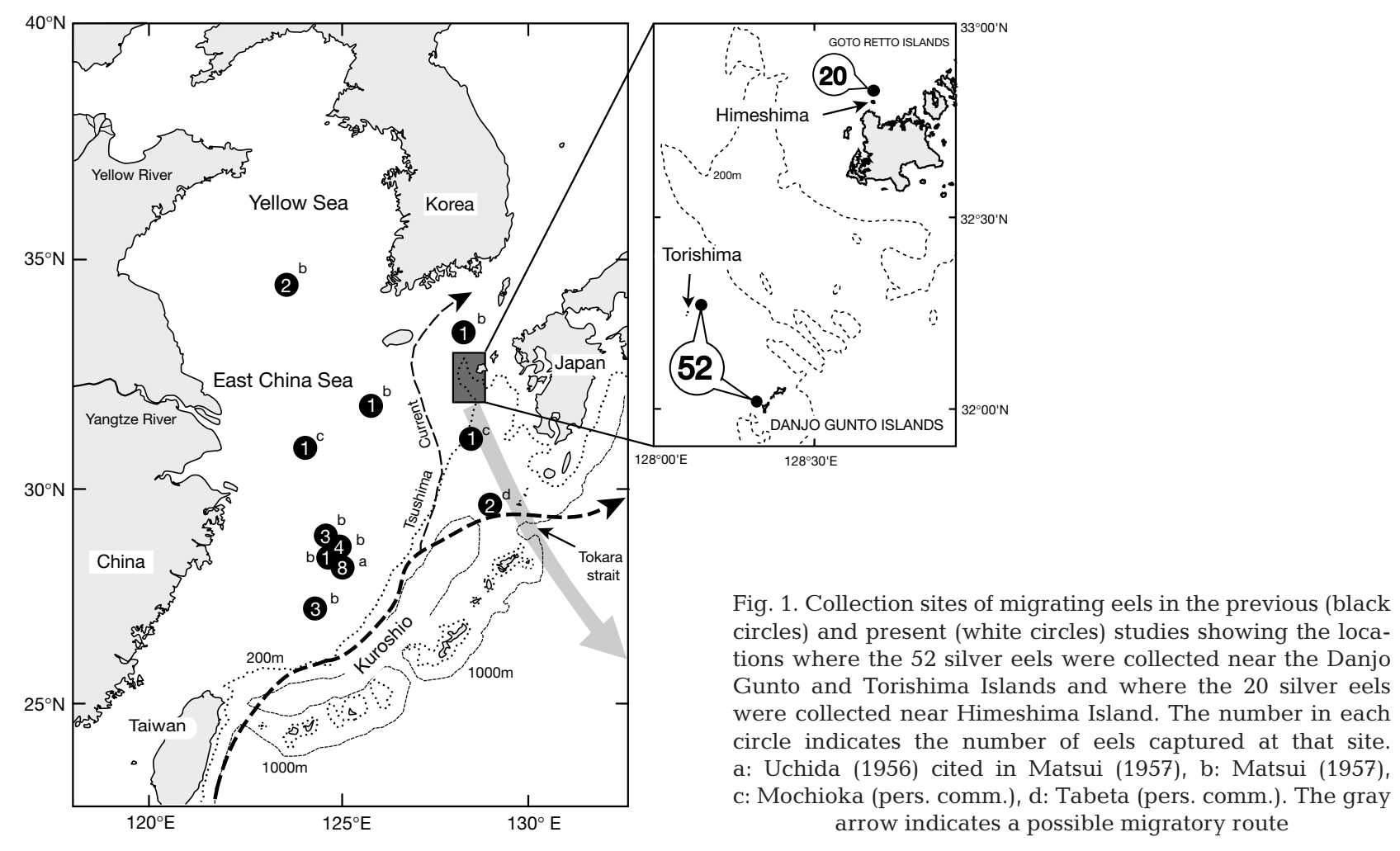

Materials and methods. Sampling sites: Japanese eels were collected around the Danjo Gunto and Torishima Islands (Danjo area) and around Himeshima Island (Himeshima area), in the northeast region of the East China Sea, November to March, 1993 to 1999 (Fig. 1). The Danjo Gunto Islands are 5 small islands spread out over $10 \mathrm{~km}$. The only species of Anguilla reported in this area is A. marmorata, which inhabits small streams of the islands (Tabeta pers. comm.). The Torishima Islands consist of 2 small rock islands. The sampling points were 1 to $2 \mathrm{~km}$ away from the islands at depths between 120 to $160 \mathrm{~m}$. Himeshima Island is a small island that is adjacent to the Goto Retto Islands, where both $A$. japonica and $A$. marmorata occur. The collection area was within a radius of $5 \mathrm{~km}$ from Himeshima Island, at water depths ranging from 50 to $80 \mathrm{~m}$.

Collection and morphological measurements: All eels were captured at night with dip nets when they approached boats $(7.5 \mathrm{t}$ ) that were fishing for yellowtail and northern bluefin tuna using hook and line. Fishing usually occurred from the evening to the next morning, and all eels were captured under artificial lighting at the surface. Captured eels were examined in the following manner. The total, predorsal, ano-dorsal and preanal lengths and eye diameters were measured, and the total body weights and gonad weights were also measured. The gonad and body weights were used for calculation of the GSI (gonad somatic index). The GSI values were calculated as follows:

$$
\text { GSI = gonad weight }(g) \times 100 / \text { body weight }(g)
$$

The eye diameter was measured for calculation of the eye index according to Pankhurst (1982) as follows:

$$
\text { Eye index }=\left\{[(A+B) / 4]^{2} \times \pi / L\right\} \times 100
$$

where $A$ is the horizontal eye diameter, $B$ the vertical eye diameter and $L$ is the total length. Damaged specimens were excluded from calculations of the GSI and the eye index. Some pieces of the liver were taken from each eel and preserved in ethanol for subsequent genetic analyses for species identification using DNA.

Identification of species: Species identifications were made using polymerase chain reaction-restriction fragment length polymorphism (PCR-RFLP) analysis of the mitochondrial 16S ribosomal RNA gene, and this procedure is described in Aoyama et al. (2000a). Out of 42 eels from the Danjo area and the Himeshima area that were examined for species identification, 41 specimens were identified as Japanese eels and one as a European eel $A$. anguilla. There were no A. marmorata among the samples. The European eel, although it also was a silver eel (GSI $=2.66)$, was excluded from the following analysis. The details of this genetic analysis will be reported elsewhere (Aoyama et al. 2000b). 


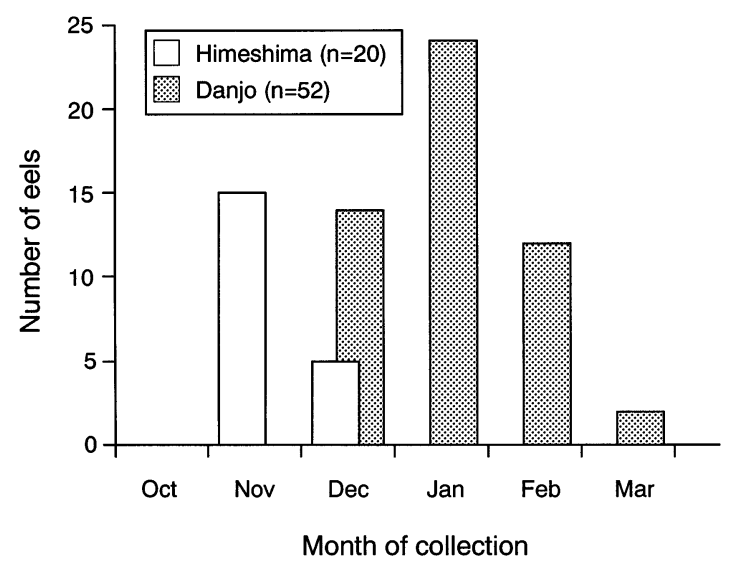

Fig. 2. Number of eels collected in the East China Sea from October to March, 1993 to 1999

Results. Behavioral and seasonal patterns of occurrence: All the silver eels collected during this study were caught in dip nets as they approached the zone of light around the fishing boats ( 20 to $30 \mathrm{~m}$ ) during complete darkness, but none were seen at dusk or dawn. These eels were readily captured because they swam slowly at the surface, but they usually disappeared after a 5 to 10 min stay near the boat. A total of 72 eels were collected from 1993 to 1999 at the Danjo $(n=52)$ and Himeshima areas $(\mathrm{n}=20)$, and these included more females $(n=60)$ than males $(n=12)$.

There was a clear difference in the seasonal patterns of the collection of silver eels between the 2 sampling locations from 1993 to 1999 (Fig. 2). At the Danjo area, a total of 52 silver eels were collected between December and March, with a peak in January, but none were collected in October and November despite substantial fishing effort. In contrast, all of the 20 silver eels caught at the Himeshima area were collected in November and December, with a peak in November.

External morphological characteristics: The size ranges of silver eels were similar between the 2 sampling areas, with females reaching much larger sizes. The average total length of females was $686 \pm 99 \mathrm{~mm}$ (range: 417 to $895 \mathrm{~mm}$ ) in the Danjo area and $715 \pm 124 \mathrm{~mm}$ (range: 513 to $1051 \mathrm{~mm}$ ) in the Himeshima area. The average total length of males in the Danjo area was $504 \pm 50 \mathrm{~mm}$ (range: 446 to $574 \mathrm{~mm}$ ), and the 2 males caught at the Himeshima area were 468 and $516 \mathrm{~mm}$ long. There was no significant difference in total length between females from the Danjo and Himeshima areas (Mann-Whitney $U$-test, $\mathrm{p}=0.55$ ). Consistent with other species of Anguilla (Burnet 1969, Todd 1980, Vøllestad 1992, Krueger \& Oliveira 1997), the females collected during this study were significantly larger than the males (Mann-Whitney $U$-test, $\mathrm{p}<0.001$ ). No eels smaller than $400 \mathrm{~mm}$ were collected or observed.
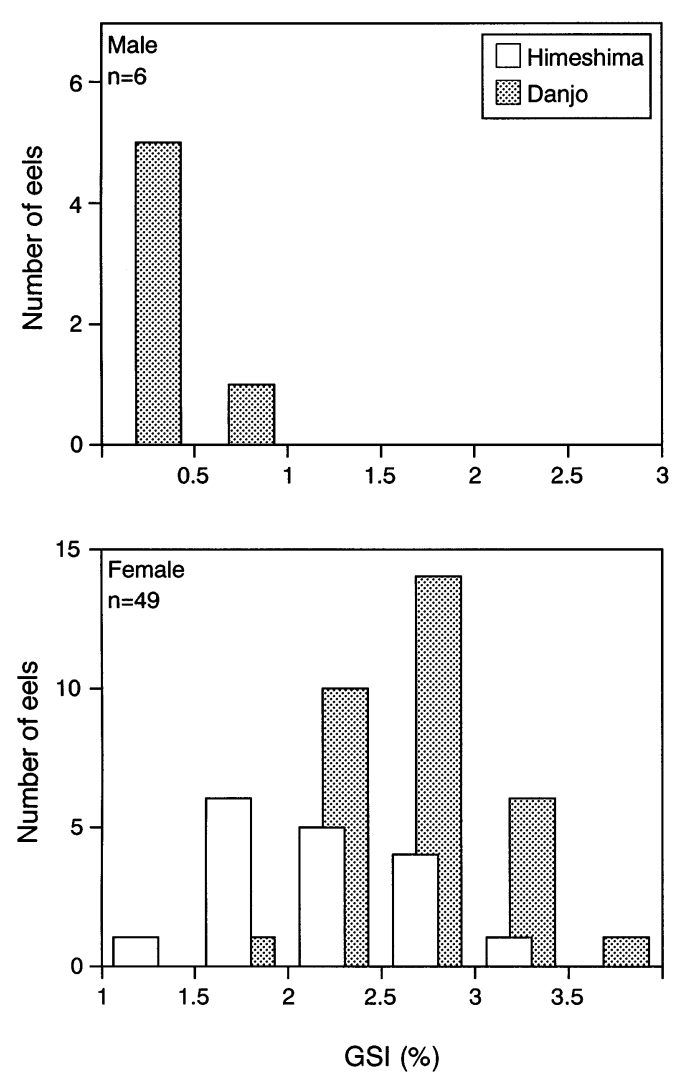

Fig. 3. Gonad somatic indices (GSI) of eels collected in the East China Sea

The external characteristics of all the individuals collected during this study were typical of silver phase eels. The dorsolateral portion was dark, and the belly and flank were bronze with metallic silver spots. The pectoral fins were dark black with a golden color at the base. The eye index of the eels in the Danjo and Himeshima areas ranged from 3.3 to 8.0, and 3.2 to 7.0 , respectively. The eye index values in the Danjo area were significantly higher than those in the Himeshima area (Mann-Whitney $U$-test, $\mathrm{p}<0.01$ ), suggesting that the silver eels from the Danjo area were at a more advanced stage of maturation.

Gonadal morphology: All the female silver eels had relatively large ovaries. Their GSI values ranged from 1.9 to 3.5 at the Danjo area and from 1.3 to 3.0 at the Himeshima area (Fig. 3). The values of the silver eels in the Danjo area were significantly higher than those in the Himeshima area (Mann-Whitney $U$-test, $\mathrm{p}<0.01$ ). Males had small but recognizable testes, and the 6 individuals from the Danjo area that were available for analysis ranged from 0.2 to 0.6 , with an average of $0.4 \pm 0.14$ (Fig. 3)

Discussion. Seasonal pattern of early marine migration: Our findings of 72 silver eels in the Danjo and 
Himeshima areas over a period of 7 yr have greatly increased the number of known reports of only 28 silver eels collected over $50 \mathrm{yr}$ (Table 1). All but 1 of these 100 silver eels, which was caught in September, were collected between November and March, with December and January apparently being the most common months of occurrence among all the reports. The fishing boats that captured the silver eels described in this study also fished in the same areas during summer and reported no sightings of eels during that season ( $\mathrm{T}$. Kusano pers. comm.).

The Japanese eel as well as the other temperate anguillid species make their spawning migration as silver eels during the fall and winter. The silver eels of Anguilla japonica (Matsui 1957, 1972), the American eel A. rostrata (Jessop 1987), the European eel $A$. anguilla (Tesch 1977, Vøllestad et al. 1986), and the Australian and New Zealand species A. australis and A. dieffenbachii (Todd 1981, Sloane 1984, Jellyman 1987) all descend freshwater rivers and streams in fall and enter saltwater, where they begin their marine migration to the open ocean spawning areas. The timing of capture and morphology of silver eels at the 2 sites sampled during this study suggested that the eels collected in the Himeshima area were closer to their original juvenile habitats, because they were collected earlier (November and December) and at a lessadvanced stage of maturation than those collected in the Danjo area (December to March) further to the south.

Reproductive and migratory state of eels: The bronze integument and the large black pectoral fins that were observed in the eels from the Danjo and Himeshima areas are characteristic of the silver phase but are never seen in the yellow phase, although col- oration is not always related to degree of maturity (Pankhurst \& Lythgoe 1982, Jessop 1987). In addition, the GSI values of females at the Danjo (1.9 to 3.5) and Himeshima (1.3 to 3.0) areas were as high or higher than those of female silver eels collected during their downstream migration in freshwater in Japan (1.1 to 2.5; S.S. unpubl. data). The higher eye indices in the Danjo eels (3.3 to 8.0) compared to the Himeshima eels (3.2 to 7.0 ), or to those of similar size in freshwater (3.3 to 6.9 ; S.S. unpubl. data), also indicated that the silver eels collected farthest offshore at Danjo area were at a more advanced stage of sexual maturation. These results suggest that the silver eels collected at the Danjo area were the most sexually advanced specimens ever reported for Anguilla japonica (Matsui 1957, Ogata 1991).

It has generally been assumed that the silver eels collected in the East China Sea were individuals that had descended freshwater rivers and streams and were in the process of migrating to the spawning area, but recent findings indicate that these eels may have originated from a variety of different marine and freshwater habitats. Tsukamoto et al. (1998) have recently used analyses of the Sr/Ca ratios in the otoliths of 12 eels from the Danjo area to demonstrate that those individuals had spent their entire lives in seawater ('sea eels'), and had not been residing in freshwater during their juvenile growth phase. Similarly, Tsukamoto \& Arai (2001) used the same technique with different samples from a wider geographic area and found sea eels in the Danjo area and at several other coastal locations around Japan. However, they also reported that in addition to 5 purely marine sea eels in the Danjo area, there were 4 individuals that appeared to have inhabited estuarine habitats and 3 others that

Table 1. Records of silver eels in the East China Sea

\begin{tabular}{|c|c|c|c|c|c|c|}
\hline Date & Location & $\begin{array}{c}\text { No. } \\
\text { of eels }\end{array}$ & $\begin{array}{l}\text { Total length } \\
(\mathrm{mm})\end{array}$ & $\begin{array}{l}\text { Body weight } \\
\text { (g) }\end{array}$ & Sex & Source \\
\hline Dec 5, 1952 & $\begin{array}{l}\text { NW } 30 \text { miles off } \\
\text { Goto Isles }\end{array}$ & 1 & 453 & 400 & Male & Matsui (1957) \\
\hline Dec 10,1953 & $34^{\circ} 30^{\prime} \mathrm{N}, 123^{\circ} 30^{\prime} \mathrm{E}$ & 2 & 807,795 & 880,900 & Female & Matsui (1957) \\
\hline Dec 15, 1953 & $28^{\circ} 30^{\prime} \mathrm{N}, 124^{\circ} 40^{\prime} \mathrm{E}$ & 1 & 495 & 520 & Male & Matsui (1957) \\
\hline Jan 11, 1954 & $31^{\circ} 58^{\prime} \mathrm{N}, 125^{\circ} 55^{\prime} \mathrm{E}$ & 1 & 755 & 770 & Female & Matsui (1957) \\
\hline Dec 18, 1954 & $28^{\circ} 44^{\prime} \mathrm{N}, 124^{\circ} 35^{\prime} \mathrm{E}$ & 3 & - & - & 2 male, 1 female & Matsui (1957) \\
\hline Dec 20, 1954 & $28^{\circ} 45^{\prime} \mathrm{N}, 124^{\circ} 37^{\prime} \mathrm{E}$ & 4 & $486-678$ & $150-430$ & 1 male, 3 female & Matsui (1957) \\
\hline Jan 10, 1956 & $27^{\circ} 35^{\prime} \mathrm{N}, 124^{\circ} 15^{\prime} \mathrm{E}$ & 3 & 512 & 180 & Female & Matsui (1957) \\
\hline Dec 22, 1954-Jan 8, 1956 & $\begin{array}{l}27^{\circ} 50^{\prime} \mathrm{N}-28^{\circ} 40^{\prime} \mathrm{N} \\
124^{\circ} 40^{\prime} \mathrm{E}-125^{\circ} 02^{\prime} \mathrm{E}\end{array}$ & 8 & $472-745$ & $143-580$ & Female & $\begin{array}{l}\text { Utida (1956) cited in } \\
\text { Matsui (1957) }\end{array}$ \\
\hline Sep 1975 & Mid East China Sea & 1 & 500 & - & Female & Tabeta (1980) \\
\hline Nov 30, 1988 & $30^{\circ} 59^{\prime} \mathrm{N}, 124^{\circ} 00^{\prime} \mathrm{E}$ & 1 & 448 & 124.3 & Male & Mochioka (pers. comm.) \\
\hline Dec 12, 1988 & $31^{\circ} 20^{\prime} \mathrm{N}, 128^{\circ} 07^{\prime} \mathrm{E}$ & 1 & 613 & 331.4 & Female & Mochioka (pers. comm.) \\
\hline Jan 25, 1990 & $29^{\circ} 40^{\prime} \mathrm{N}, 128^{\circ} 40^{\prime} \mathrm{E}$ & 2 & 692,602 & 685,260 & Female & Tabeta (pers. comm.) \\
\hline Dec 1993-Dec 1998 & Himeshima area & 20 & $513-1051$ & $116-1961$ & 2 male, 18 female & Present study \\
\hline Feb 1994-Jan 1999 & Danjo area & 52 & $417-895$ & $82.7-1215$ & 10 male, 42 female & Present study \\
\hline
\end{tabular}


had only inhabited freshwater habitats as juveniles before starting their reproductive migration into the ocean. This finding of individuals from a variety of habitats, and not just purely marine habitats, suggests that the eels collected during this study were in the process of migrating to the spawning area in the same way as eels from freshwater that exhibit the typical life history pattern of Anguilla japonica.

Possible migratory pathway for silver eels: The consistent presence of silver eels collected in the Danjo and Himeshima areas over a $7 \mathrm{yr}$ period suggests that there are maturing eels passing through this region each year during the spawning season of Anguilla japonica and that it may be part of a regular migratory route for eels from some areas. If migrating silver eels swim directly towards the spawning area, the study sites are almost exactly in line with a direct vector to the spawning area for eels migrating from the eastern and southern coasts of the Korean Peninsula (Fig. 1). Or if silver eels have a tendency to seek deeper water as they migrate over the continental shelf, some may pass through the study area as a result of moving towards the deepest part of the shelf. Telemetry studies of silver eels $A$. anguilla in the Mediterranean Sea have indicated that individuals tend to move directly to deeper water with frequent movements toward the bottom when in shallow water during the day and to shallower swimming depths including movements up to the surface at night (Tesch 1989). Silver eels tracked over relatively shallow water also showed vertical movements with frequent contact with the bottom (McCleave \& Arnold 1999), which could be a tactic to facilitate movement towards deeper water. The bottom topography of the East China Sea tends to slope down toward a submarine canyon that is between the study areas (Chough 1983). This canyon and the Tokara Strait are thought to be the mouth of the ancient Yellow River that is now located in northeastern China (Kimura 1996) and is at the eastern edge of the Tsushima Warm Current. An anticyclonic eddy has been observed over this canyon during various studies in late fall and winter (Qiu et al. 1990, Chen et al. 1992, Sugimoto \& Tameishi 1992, Lie \& Cho 1994). Therefore, if migrating eels tend to seek the deepest areas during the initial stage of their marine migration, the location of this canyon may cause some eels to pass through the area based on their movements toward deeper water and they would also avoid swimming directly against any substantial northward flow of the Tsushima Warm Current. In addition, water temperatures in this area are warmer than to the west on the other side of the Tsushima Warm Current (Lie \& Cho 1994) and are similar to the apparent preferred water temperature of silver phase American eels of 17 to $20^{\circ} \mathrm{C}$ (Haro 1991).
The silver eels from other areas adjacent to the Yellow and East China Seas may also have been migrating toward the spawning area when they were collected at the locations described in the previous reports (Table 1, Fig. 1). Further studies should focus on conducting grid surveys to standardize catch per unit effort in order to learn more about the distribution, life-history characteristics and possible migratory routes of silver eels in the East China Sea; telemetry studies should be used to examine the individual behavior of the Japanese eel during its spawning migration.

Acknowledgements. We express our sincere thanks to $\mathrm{Mr}$ Tsuchio Kusano, a fisherman of Goto Retto Islands, for providing silver eels and for giving us the opportunity to collect eels on his fishing boat. This study was supported in part by Grants-in-Aid (Nos. 08041139, 10460081, 11691177) from the Ministry of Education, Science and Culture, Japan, the Eel Research Foundation from Nobori-kai, and the Research Foundation from Touwa Shokuhin Shinkoukai. Partial support was also given in the form of Research Fellowships of the Japan Society for the Promotion of Science for Young Scientists to S.S. and J.A.

\section{LITERATURE CITED}

Aoyama J, Watanabe S, Nishida M, Tsukamoto K (2000a) Discrimination of catadromous eel species, genus Anguilla, using PCR-RFLP analysis of the mitochondrial 16SrRNA domain. Trans Am Fish Soc 129:873-878

Aoyama J, Watanabe S, Miyai T, Sasai S, Nishida M, Tsukamoto K (2000b) The European eel, Anguilla anguilla (L.), in Japanese waters. Dana 12:1-5

Arai T, Otake T, Tsukamoto K (1997) Drastic changes in otolith microstructure and microchemistry accompanying the onset of metamorphosis in the Japanese eel Anguilla japonica. Mar Ecol Prog Ser 161:17-22

Bast HD, Klinkhardt MB (1988) Fang eines Silberaales [Anguilla anguilla (L., 1758)] im Iberischen Becken (Nordostatlantik) (Teleostei: Anguillidae). Zool Anz 221: 386-398

Burnet AMR (1969) Migrating eels in a Canterbury river, New Zealand. NZ J Mar Res 3:230-244

Chen C, Beardsley RC, Limeburner R (1992) The structure of the Kuroshio southwest of Kyushu: velocity, transport, and potential vorticity fields. Deep-Sea Res 39:245-268

Chough SK (1983) Marine geology of Korean Seas. D Reidel Publishing Company, Dordrecht

Ernst P (1975) Catch of an eel (A. anguilla) northeast of the Faroe Islands. Ann Biologiques Cons Perm Explor Mer 32: 175

Haro AJ (1991) Thermal preferenda and behavior of Atlantic eels (genus Anguilla) in relation to their spawning migration. Environ Biol Fishes 31:171-184

Honma Y (1966) Notes on the catadromous eels obtained from off the coast of Niigata, the Sea of Japan, with special reference to the histology of some of the organs. La Mer 4(4): 241-260

Jellyman DJ (1987) Review of the marine life history of Australasian temperate species of Anguilla. Am Fish Soc Symp 1:276-285 
Jessop BM (1987) Migrating American eels in Nova Scotia. Trans Am Fish Soc 116:161-170

Kawakami Y, Mochioka N, Nakazono A (1999) Immigration patterns of glass-eels Anguilla japonica entering river in northern Kyushu, Japan. Bull Mar Sci 64(2):315-327

Kimura M (1996) Quaternary paleogeography of the Ryukyu arc. J Geogr 105(3):259-285

Krueger WH, Oliveira K (1997) Sex, size, and gonad morphology of silver American eels Anguilla rostrata. Copeia 2: $415-420$

Lie H, Cho C (1994) On the origin of the Tsushima Warm Current. J Geophys Res 99:25081-25091

Matsui I (1957) On the record of a leptocephalus and catadromous eels of Anguilla japonica in the waters around Japan with a presumption of their spawning places. J Shimonoseki Coll Fish 7:151-167

Matsui I (1972) Eel biology-biological study. KoseishaKoseikaku, Tokyo

McCleave JD, Arnold GP (1999) Movements of yellow- and silver-phase European eels (Anguilla anguilla L.) tracked in the western North Sea. ICES J Mar Sci 56:510-536

Ogata T, Iwata K, Kudo K, Terayama M (1991) A catadromous eel (Anguilla japonica) captured from Hyuga nada. Bull Jpn Soc Fish Oceanogr 55(3):183-188

Pankhurst NW (1982) Relation of visual changes to the onset of sexual maturation in the European eel Anguilla anguilla (L.). J Fish Biol 21:127-140

Pankhurst NW, Lythgoe JN (1982) Structure and colour of the integument of the European eel Anguilla anguilla (L.). J Fish Biol 21:279-296

Qiu B, Toda T, Imasato N (1990) On Kuroshio front fluctuations in the East China Sea using satellite and in situ observational data. J Geophys Res 95:18191-18204

Reinsch HH (1968) Fund von Aalen Anguilla anguilla (L.) im Nordatlantik. Arch Fischereiwiss 19:62-63

Sloane RD (1984) Preliminary observations of migrating adult freshwater eels (Anguilla australis australis Richardson) in Tasmania. Aust J Mar Freshw Res 35:471-476

Sugimoto T, Tameishi H (1992) Warm-core rings, streamers

Editorial responsibility: Otto Kinne (Editor),

Oldendorf/Luhe, Germany and their role on the fishing ground formation around Japan. Deep-Sea Res 39:S183-S201

Tabeta O (1980) Migration of the eel. Saishu to Shiiku 42: 84-86

Tesch FW (1977) The eel biology and management of anguillid eels. Chapman and Hall, London

Tesch FW (1989) Changes in swimming depth and direction of silver eels (Anguilla anguilla L.) from the continental shelf to the deep sea. Aquat Living Resour 2:9-20

Todd PR (1980) Size and age of migrating New Zealand freshwater eels (Anguilla spp.). NZ J Mar Freshw Res 14: 283-293

Todd PR (1981) Timing and periodicity of migrating New Zealand freshwater eels (Anguilla spp.). NZ J Mar Freshw Res 15:225-235

Tsukamoto K (1990) Recruitment mechanism of the eel, Anguilla japonica, to the Japanese coast. J Fish Biol 36: $659-671$

Tsukamoto K (1992) Discovery of the spawning area for Japanese eel. Nature 356:789-791

Tsukamoto K, Arai T (2001) Facultative catadromy of the eel Anguilla japonica between freshwater and ocean habitats. Mar Ecol Prog Ser (in press)

Tsukamoto K, Nakai I, Tesch FW (1998) Do all freshwater eels migrate? Nature 396:635-636

Tzeng WN (1990) Relationship between growth rate and age at recruitment of Anguilla japonica elvers in a Taiwan estuary as inferred from otolith growth increments. Mar Biol 107:75-81

Vøllestad LA (1992) Geographic variation in age and length at metamorphosis of maturing European eel: environmental effects and phenotypic plasticity. J Anim Ecol 61:41-48

Vøllestad LA, Jonsson B, Hvidsten A, Næsje TF, Haraldstad $\varnothing$, Ruud-Hansen J (1986) Environmental factors regulating the seaward migration of European silver eels (Anguilla anguilla). Can J Fish Aquat Sci 43:1909-1916

Wenner CA (1973) Occurrence of American eels, Anguilla rostrata, in waters overlying the eastern North American continental shelf. J Fish Res Board Can 30:1752-1755

Submitted: August 21, 2000; Accepted: January 25, 2001 Proofs received from author(s): February 23, 2001 